\title{
MORPHOLOGICAL EVIDENCE BY SCANNING ELECTRON MICROSCOPY OF EXCRETION OF METACYCLIC FORMS OF TRYPANOSOMA CRUZI IN VECTOR'S URINE
}

\author{
RODRIGO ZELEDON*, RODOLFO BOLAÑOS**, M. R. ESPEJO NAVARRO*** \& \\ MIGUEL ROJAS*
}

\begin{abstract}
* Escuela de Medicina Veterinaria, Universidad Nacional and Centro de Investigación en Biología Celular y Molecular, Universidad de Costa Rica, San José, Costa Rica ** Unidad de Microscopía Electrónica, Universidad de Costa Rica *** Istituto de Medicina Tropical "Daniel A. Carrión", Universidad Nacional de San Marcos, Lima, Perú
\end{abstract}

Comparision by scanning electron microscopy (SEM) of Trypanosoma cruzi flagellates attached to the cuticle of the rectal gland of infected Dipetalogaster maxima nymphs, showed marked differences before and after feeding. Before feeding numerous metacyclic trypomastigotes were observed among the abundant epimastigotes that formed the carpet of flagellates. On the other hand, in insects that were allowed to urinate for 24 hours after a meal, the metacyclics were scarce, indicating that they had been detached by the urine flow. An asymetric type of cell division, probably originating both an epi-and a trypomastigote, was occasionally observed. The occurrence of swellings at different levels of the flagella of epimastigotes suggests that secondary sites of attachment may be common.

Key words : Trypanosoma cruzi - Dipetalogaster maxima - metacyclogenesis - scanning electron microscopy - epimastigotes - life cycle

The preferencial colonization of Trypanoso$m a$ cruzi on the rectal gland in the hindgut of its triatomine vectors has been observed both by transmission (TEM) and scanning electron microscopy (SEM) (Zeledón et al., 1977; 1984). It has been shown that both epimastigotes and trypomastigotes of the metacyclic type tend to cover the surface of the gland, forming a compact layer attached to the epithelium by flagella hemidesmosomes. The marked "predominance of epimastigotes with a rounded posterior free portion" was also observed in this flagellate carpet (Zeledón et al., 1984). Böker \& Schaub (1984) basically confirmed these findings but they noticed different types of epimastigotes, with short and long forms on both the rectal gland and other areas of the rectal sac. Several authors (Dias, 1934; Zeledón et al., 1977; Chowdhury \& Fistein, 1986) have also shown that metacyclic forms appear in the urine of insects after a blood meal, and practically no epimastigotes are seen at that time.

This investigation received financial support from the Vicerrectoría de Investigación, Project No 02-01-0829, University of Costa Rica, and from the UNDP/ World Bank/WHO Special Programme for Research and Training in Tropical Diseases.

Received February 18, 1988.

Accepted April 19, 1988.
In order to observe if frequent micturitions could have an effect on the proportion of epiand trypomastigotes on the rectal gland, we set up an experiment using SEM.

\section{MATERIALS AND METHODS}

We selected 20 fifth instar nymphs of Dipetalogaster maxima, of a group infected five months previously with $T$. cruzi (CR-4 strain) on a guinea pig. The insects were starved for one month, then half of them were fed on pigeons. After repletion, they were allowed to urinate during 24 hours. All 20 insects were killed by submerging the head in boiling water and were dissected after injection of a $6 \%$ glutaraldehyde solution in phosphate buffer $(\mathrm{pH}$ 7.2) into the rectal sac (Böker \& Schaub, 1984). For observations by SEM, we followed the procedure previously described (Zeledón et al., 1984), using instead a Hitachi S-570 microscope.

\section{RESULTS}

Comparision of the flagellates on the rectal glands of unfed insects and those that urinate for 24 hours after a blood meal, showed marked differences in aspect. In the former, many typical metacyclic trypomastigotes were easily 


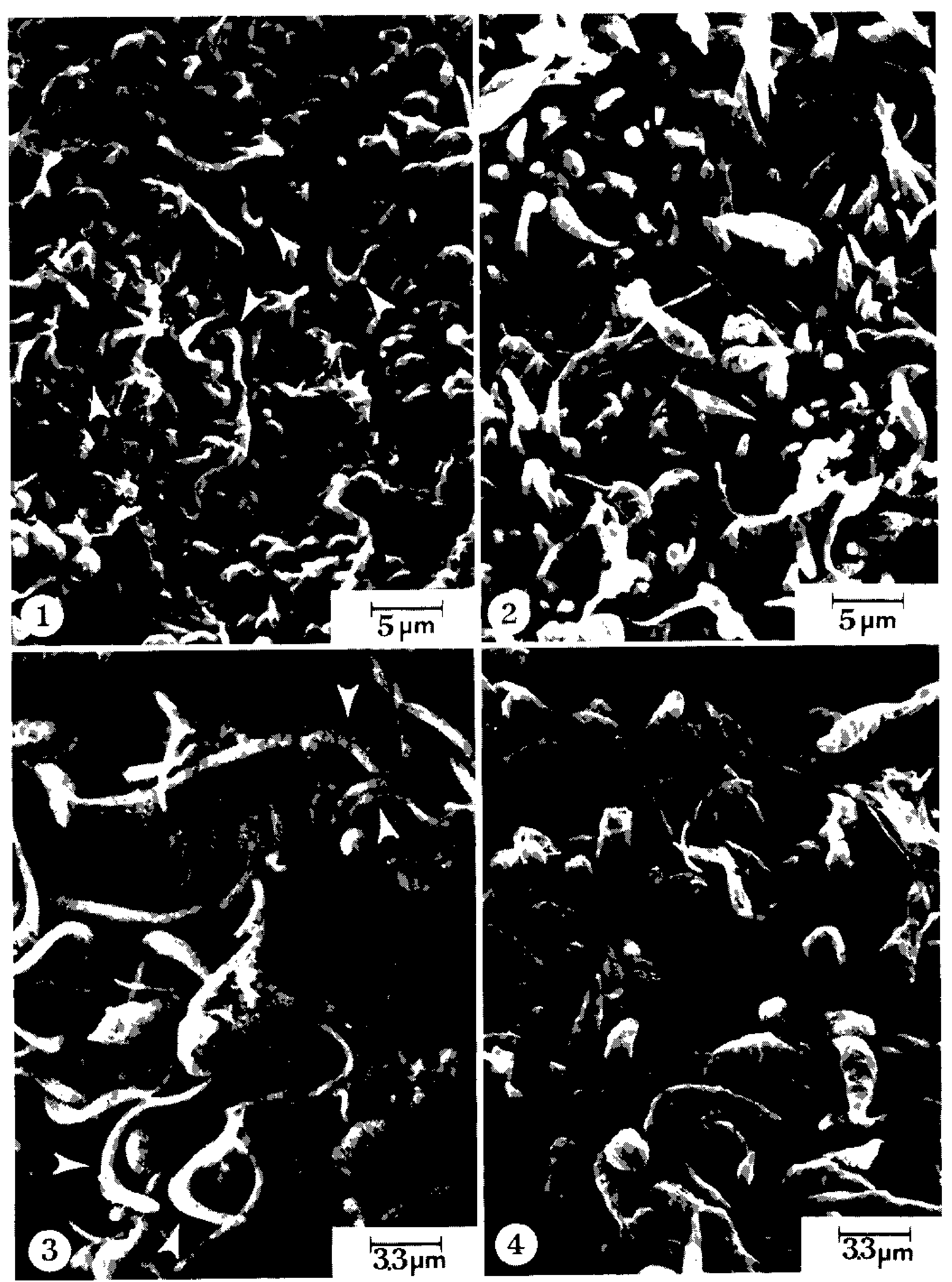

Surface of the rectal gland of Dipetalogaster maxima nymph infected with Trypanosoma cruzi. ligs. 1-3: Before feeding. Numerous metacyclic trypomastigotes (arrowed) are observed among the epimastigotes. $x 2000$ and $x$ 3000. Figs. 2-4: After feeding. Metacyclic trypomastigotes are scarce. $\times 2000$ and $\times 3000$. 

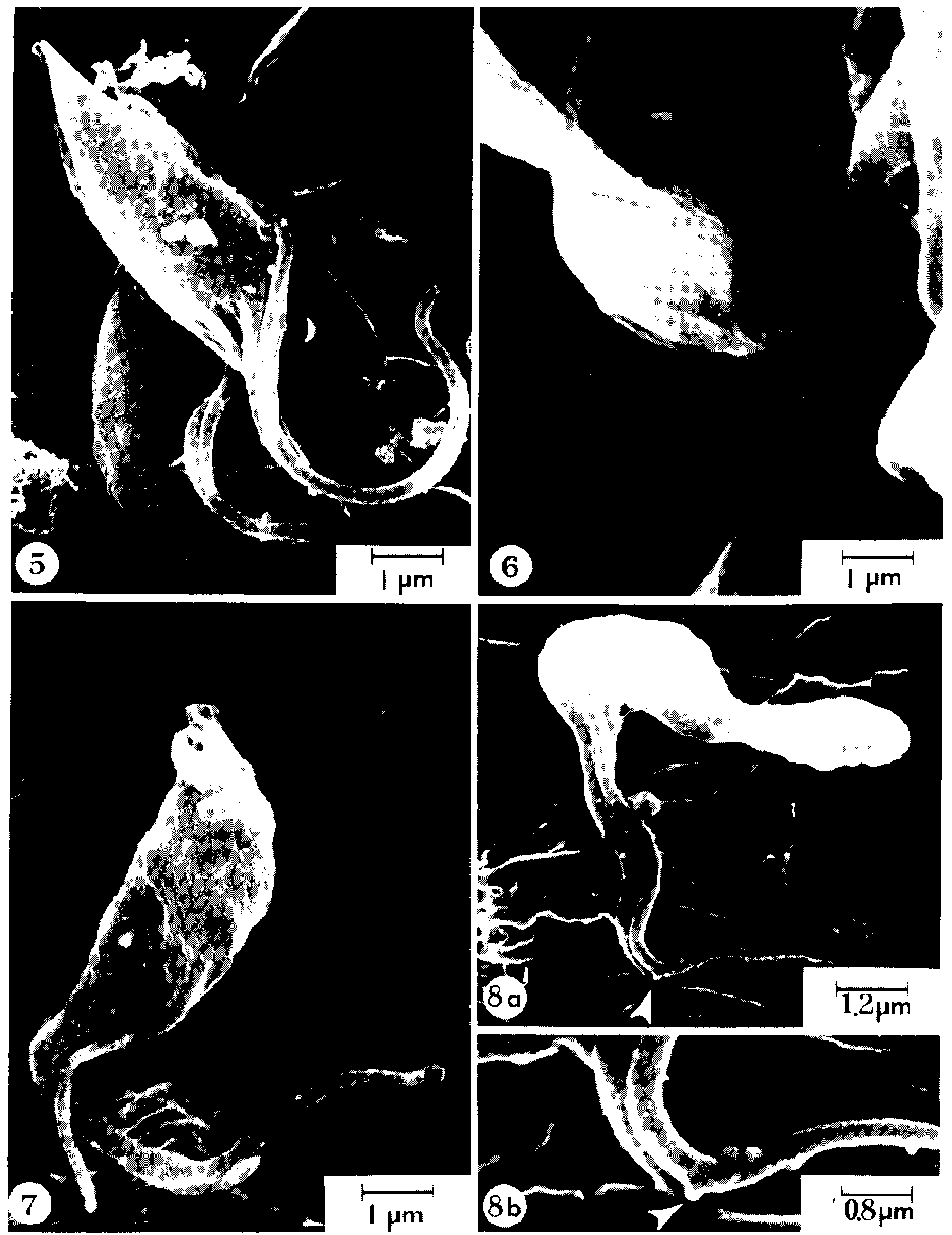

Figs. 5-7: Dividing epimastigotes anchored to the surface of the epithelium of the rectal sac. Fig. 7: An asymmetric cell division is evident. $x$ 9000. Fig. 8 a: An epimastigote showing flagellar swellings (arrowed), attached to the surface of the cuticle. $x$ 8500. Fig. 8.b: Detail of part of the flagellum. $x 12000$. 
distinguished among the more numerous epimastigotes of different types and sizes (Figs. 1 and 3 ). In the second group of insects the metacyclics were notably fewer and sometimes not easy to detect (Figs. 2 and 4). This picture was consistent in all insects making it easy to separate both groups even without knowing the source of the preparation. Some isolated forms, particularly those attached to the rectal sac, were in cell division, which in one case was asymmetric, suggesting the birth of an api- and a trypomastigote (Figs. 5, 6 and 7). Small flagellar swellings, protruding from the flagellum at different levels, were also observed. These seem to be secondary sites of attachment to the cuticle (Fig. 8).

\section{DISCUSSION}

We have previously demonstrated the presence of numerous epimastigotes with rounded posterior end among those forms attached to the surface of the rectal gland (Zeledón et al., 1984). Bòker \& Schaub (1984) also observed epimastigotes of different sizes, some elongated with a tapering posterior end, which we have confirmed in the present study. While the proportion of all these types of epimastigotes can vary with the strain of the parasite and with the species of insect involved, they may all be present at a given time. In our previous experiments we dissected the insects in saline solution and washed the rectal sac with PBS before fixation with glutaraldehyde. However, we suspected that we may have been detaching the metacyclic forms that we had thought were normally very scarce. Prior fixation of the rectal sac, as described by Böker \& Schaub (1984), confirmed our suspicion. Brooker (1971) observed that the addition of distilled water to the gut of mosquitoes infected with Crithidia fasciculata, triggered the detachment of this flagellate from the surface. In the case of $T$. cruzi, detachment seems to be triggered by the dilute urine abundantly produced after a full blood meal. Zeledón et al. (1977) observed that an almost pure culture of metacyclic forms is expelled by the insect between the second and the fifth excretion drops. At this time these forms may reach numbers as high as $52.5 \times 10^{6}$ per ml of urine. Since metacyclics as well as epimastigotes are both attached to the surface of the gland, which is located at the site where the four Malpighian tubes discharge the urine, we have to assume that the former are more easily detached and subsequently flushed out, an explanation which coincides with the morphological picture in our present model.

It also seems evident that metacyclic forms originate by at least two mechanisms. Some epimastigotes are directly transformed and others produce a trypomastigote and a epimastigote by an asymmetrical type of cell division. This latter mechanism was observed by Camargo (1964) in cultures.

Whether the production of flagellar expansions in certain areas provides for further attachments to the surface of the cuticle in order to guarantee better anchorage of the flagellates, and whether this is a peculiar characteristic of epimastigotes, still has to be demonstrated.

It now seems evident that the excretory system of the insect plays a basic and dual role in the life cycle and also in transmmission of the parasite, and there is sound support for the argument that flagellates attach preferentially to the rectal gland of the insect, although they could, particularly in old infections, fill up other spaces of the rectal sac, where metacyclogenesis may also take place (Böker \& Schaub, 1984; Zeledón \& Rojas, unpublished data).

\section{RESUMO}

Evidência morfológica de formas metacíclicas do Trypanosoma cruzi em urina de vetores, através da microscopia eletrônica de varredura - Observando-se, em microscopia eletrônica de varredura, formas flageladas do Trypanosoma cruzi presas à cutícula da glândula retal de ninfas infectadas de Dipetalogaster maxima, verificaram-se nítidas diferenças antes e depois da alimentação. Antes, viam-se numerosos tripomastigotas metacíclicos entre os abundantes epimastigotas que formavam o tapete de flagelados, ao passo que nos insetos que urinavam dentro das 24 horas após o repasto os metacíclicos eram raros, indicando que haviam sido desprendidos pelo fluxo urinário. Foi notado, às vezes, um tipo assimétrico de divisão celular, originando um epi e um tripomastigota. Nos flagelados dos epimastigotas a presença de dilataçōes a diferentes níveis sugere que lugares secundários de aderência podem ser comuns.

Palavras-chave : Trypanosoma cruzi - Dipetalogaster maxima - metaciclogênese - microscopia eletrônica de varredura - ciclo evolutivo 


\section{REFERENCES}

BÖKLR, C. A. \& SCHAUB, G. A., 1984. Scanning electron microscopic studies of Trypanosoma cruzi in the rectum of its vector Triatoma infestans. Z. Parasitenk. 70:459-469.

BROOKER, B. L., 1971. Flagellar attachment and detachment of Crithidia fasciculata to the gut wall of Anopheles gambiae. Protoplasma, 73:191-202.

CAMARGO, E. P., 1964. Growth and differentiation in Trypanosomo cruzi. 1. Origin of metacyclic trypanosomes in liquid media. Rev. Inst. Med. Trop. São Paulo, 6: 93-100.

CHOWDHURY, M. N. H. \& IFISTEIN, B., 1986.
Excretion of Trypanosome cruzi by various stagts of Rhodnius prolixus. Intem. J. Parasitol. It. 353-359.

DIAS, E., 1934. Estudos sobre o Schizotrnpanum cruzi. Mem. Inst. Oswaldo Cruz, 28: 1-110.

ZELEDON, R. ; ALVARENGA, N. J. \& SCHOSINSK Y, K., 1977. Ecology of Trypanosoma crazi in the insect vector, p. 59-70. In: Chagas' disease sy'mpo. sium, PAHO Sc. Publ. 347.

ZELEDON, R.; BOLAÑOS, R. \& ROJAS, M., 1984. Scanning electron microscopy of the final phise of the life cycle of Trypanosoma cruzi in the insect vector. Acta Trop., $41: 39-43$. 